\title{
Quantitative Estimation and Validation of Chlorthlidone and Azilsartan Medoximil in Bulk and Tablet Dosage Form by using RP-HPLC
}

\author{
Nachiket S. Dighe*, Somnath K.Thorat, Ganesh S Shinde, Kavita V Dhamak \\ Department of Pharmaceutical Chemistry,Pravara Rural College of Pharmacy, Pravaranagar,Tal-Rahata, Dist-Ahmednagar- \\ 413736, India
}

\begin{abstract}
The first reversed phase high performance liquid chromatographic method for Stability Indicating of, Azilsartan and chlorthalidone has been developed and validated to be a simple, sensitive, rapid, specific, precise, and accurate method. Chromatographic separation was achieved on Zorbax XBD-C8, $250 \mathrm{~mm} \times 4.6 \mathrm{~mm}, 5 \mu \mathrm{m}$.Buffer pH5.5: Methanol $(60: 40)$ as a mobile phase at flow rate of $1 \mathrm{ml} / \mathrm{min}$. UV detection was operated at $234 \mathrm{~nm}$ and injection volum was $25 \mu \mathrm{l}$.. The proposed method showed good linearity, accuracy, precision and was successfully applied for determination of the drugs in laboratory prepared pharmaceutical dosage forms.
\end{abstract}

Keywords: Azilsartan and chlorthalidone, RP-HPLC, Stability Indicating.

Article Info: Received 12 June 2019; $\quad$ Review Completed 25 July 2019; Accepted 30 July 2019; $\quad$ Available online 15 August 2019

Cite this article as:

Dighe NS, Thorat SK, Shinde GS, Dhamak KV, Quantitative Estimation and Validation of Chlorthlidone and Azilsartan Medoximil in Bulk and Tablet Dosage Form by using RP-HPLC, Journal of Drug Delivery and Therapeutics. 2019; $9(4-$ s):264-268 http://dx.doi.org/10.22270/jddt.v9i4-s.3315

\section{*Address for Correspondence:}

Dr. Nachiket S. Dighe, Associate professor and head, Department of Pharmaceutical Chemistry, Pravara Rural College of Pharmacy, Pravaranagar,A/P - Loni Bk. Taluka -Rahata, Dist-Ahmednagar 413736, India (MS).

\section{INTRODUCTION:}

\section{Azilsartan Medoximil[1] :}

Azilsartan is used in the treatment of hypertention. It is a angiotensin II receptor antagonist. Its mechanism of action is blocking the angiotensin receptor by vasopressor harmone that stops vasoconstriction and thus decreases the blood pressure. Its IUPAC name is (5-methyl-2-oxo-1,3-dioxol-4yl)methyl2ethoxy-1-([2'-(5-oxo-4,5-dihydro-1,2,4oxadiazol-3- yl)biphenyl-4-yl]methyl)-1H-benzimidazole-7carboxylate and molecular formula $\mathrm{C}_{30} \mathrm{H}_{23} \mathrm{KN}_{4} \mathrm{O}_{8}$.Azilsartan was practicaly insoluble in water but soluble in DMSO and methanol. Pka of the drug was<smiles>CCOc1nc2cccc(C(=O)O)c2n1Cc1ccc(-c2ccccc2-c2nc(=O)o[nH]2)cc1</smiles>

Fig. 1 Structure of Azilsartan Medoxomil
Pharmacokinetics: Azilsartan medoxomil is quickly absorbed from the gut, independently of food intake. Maximal blood plasma concentrations are reached after one to three hours. The liver enzyme CYP2C9 is involved in the formation of the two main metabolites, which are pharmacologically inactive; they are the $O$-deethylationand decarboxylation products of azilsartan.

Adverse Drug Reaction: nausea,diarrhea,fatigue,cough.

\section{Chlorthlidone :}

. Chlorthalidone is used in the treatment of hypertension, it is a thiazide diuretic drug which inhibits $\mathrm{Na}^{+}$and $\mathrm{Cl}$ - ions reabsorption in the distal convoluted tubule by blocking the $\mathrm{Na}^{+} / \mathrm{Cl}$-Symporter. IUPAC name was $(R S)$-2-Chloro-5-(1hydroxy-3-oxo-2,3-dihydro-1H-isoindol-1-yl)benzene-1sulfonamide with molecular formula $\mathrm{C}_{14} \mathrm{H}_{11} \mathrm{ClN}_{2} \mathrm{O}_{4} \mathrm{~S}$. Chlorthalidone was soluble in Methanol, water and DMSO. Pka found was 8.76. According to literature two methods were available in which madhu et al., the retention time for Chlortalidone and AzilsartanMedoxomil were $7 \mathrm{~min}$ and 11 min respectively. Naazneen et al., the retention time for Chlortalidone and AzilsartanMedoxomil were 2.36 \pm 0.1 mins and $5.54 \pm 0.5$ minsrespectively. 
<smiles>NS(=O)(=O)c1cc(C2(O)NC(=O)c3ccccc32)ccc1Cl</smiles>

Fig. 2 Structure of Chlorthalidone

Pharmacokinetics: Chlortalidone is slowly absorbed from the gastrointestinal tract after oral ingestion. It has a long half-life and therefore a prolonged diuretic action, which results in continued diuretic effects despite a skipped dose. This prolonged action of chlortalidone despite missing doses may account for the higher efficacy of chlortalidone compared to the shorter half-life medication, hydrochlorothiazide. Chlortalidone is eliminated from the body mostly by the kidney, as unchanged drug.[2]

Adverse Drug

Reaction:Hyperuricemia,Hyperglycemia,Hyperlipidemia

MATERIAL:

DRUG:

Table 1: Drug and drug product samples suppliers and manufacturers

\begin{tabular}{|l|l|}
\hline $\begin{array}{l}\text { Name of drug and drug } \\
\text { product }\end{array}$ & $\begin{array}{l}\text { Supplier and } \\
\text { manufacturer by }\end{array}$ \\
\hline Chlorthalidone & $\begin{array}{l}\text { Amoli organics pvt } \\
\text { ltd,mumbai }\end{array}$ \\
\hline Azilsartan Medoxomil & $\begin{array}{l}\text { Honour lab limted } \\
\text { hydrabad }\end{array}$ \\
\hline $\begin{array}{l}\text { Chlorthalidone and Azilsartan } \\
\text { Medoxomil Tablet }\end{array}$ & $\begin{array}{l}\text { Ipca pharmaceutical pvt } \\
\text { ltd,Gujrat }\end{array}$ \\
\hline
\end{tabular}

\section{REAGENTS}

Table 2: List of Reagent $[3]$

\begin{tabular}{|l|l|l|}
\hline Sr.No & Chemical & Make \\
\hline 1 & Water & Rankem \\
\hline 2 & Acetonitrile & Merck life science \\
\hline 3 & Phosphoric acid $88 \%$ & Merck life science \\
\hline 4 & $\begin{array}{l}\text { Potassium dihydrogen } \\
\text { phosphate }\end{array}$ & Merck life science \\
\hline 5 & Sodium hydroxide & Merck life science \\
\hline 6 & Triethylamine & Merck life science \\
\hline 7 & $\begin{array}{l}0.45 \mu \text { Nylon membrane } \\
\text { disc filter }\end{array}$ & Mdi \\
\hline 8 & $0.45 \mu$ PVDF Syringe Filter & Mdi \\
\hline
\end{tabular}

\section{INSTRUMENTS}

Table No 3: HPLC

\begin{tabular}{|l|l|}
\hline Make & Waters e2695 \\
\hline Pump & Reciprocating Water-510 \\
\hline Detector & Waters 2695 PDA \\
\hline Software & Empower PRO \\
\hline Column & X-Bridge \\
\hline
\end{tabular}

SPECTROPHOTOMETER: Double beam UV-visible spectrophotometer with $10 \mathrm{~mm}$ Matched quartz cells

\begin{tabular}{|l|l|}
\hline Model & UV1700 \\
\hline Make & Thermo scientific \\
\hline
\end{tabular}

ANALYTICAL BALANCE: Digital Analytical balance

\begin{tabular}{|l|l|}
\hline Model & XS205D0 \\
\hline Make & Mettler Toledo \\
\hline
\end{tabular}

PH METER: Digital pH Meter

\begin{tabular}{|l|l|}
\hline Make & Thermo Scientific \\
\hline Model & Orian Star A211 \\
\hline
\end{tabular}

\section{METHOD}

\section{UV SPECTROSCOPIC2 SELECTION OF WAVELENGTH}

Preparation of Chlorthalidone Standard solution: An accurately weighed quantity about $15 \mathrm{mg}$ of Chlorthalidone standard was transferred to $200 \mathrm{~mL}$ volumetric flask. Add $150 \mathrm{~mL}$ of diluent, sonicate to dissolve and dilute up to the mark with diluent and mixed.

Preparation of Azilsartan Medoxomil Standard solution: An accurately weighed quantity about $20 \mathrm{mg}$ of Azilsartan Medoxomil standard was transferred to $100 \mathrm{~mL}$ volumetric flask. Add $70 \mathrm{~mL}$ of diluent, sonicate to dissolve and dilute up to the mark with diluent and mixed.

Preparation of Chlorthalidone Standard stock solution: Weigh accurately about $50 \mathrm{mg}$ of Chlorthalidone and transfer it into $50 \mathrm{~mL}$ amber colored volumetric flask. Add about $30 \mathrm{~mL}$ of diluent, sonicate to dissolve and make up to mark with diluent $(1.0 \mathrm{mg} / \mathrm{mL})$.

Preparation of Azilsartan Medoxomil Standard stock solution: Weigh accurately about $80 \mathrm{mg}$ of Azilsartan Medoxomil working standard and transfer it into $50 \mathrm{~mL}$ amber colored volumetric flask. Add about $30 \mathrm{~mL}$ of diluent, sonicate to dissolve and make up to mark with diluent (1.6 $\mathrm{mg} / \mathrm{mL} \mathrm{ppm).}$

Further dilute $5 \mathrm{~mL}$ each of Chlorthalidone stock solution and Azilsartan Medoxomil Standard stock solution to $50 \mathrm{~mL}$ with diluent. $(0.10 \mathrm{mg} / \mathrm{mL}$ Chlorthalidone and $0.16 \mathrm{mg} / \mathrm{mL}$ of Azilsartan Medoxomil).

Note: Prepare standard solution in duplicate as 1st standard solution and 2 nd standard solution.

\section{Preparation of Sample solution:}

Chlorthalidone and Azilsartan Medoxomil) stock solution:

Weigh and transfer 10 tablets into $1000 \mathrm{~mL}$ amber colored volumetric flask. Add about $100 \mathrm{~mL}$ of water and sonicate to disperse the tablets then add $600 \mathrm{~mL}$ of diluent, sonicate for about 60 minutes along with intermittent shaking for complete disintegration of tablets. Allow it to cool and make up to volume with diluent. Centrifuge the solution for about 10 minutes at $3000 \mathrm{rpm}$. Filter through $0.45 \mu$ Nylon membrane syringe filter. Inject stock solution for Chlorthalidone $(0.1 \mathrm{mg} / \mathrm{mL}$ of Amlodipine).Further dilute 5 $\mathrm{mL}$ of sample stock solution to $50 \mathrm{~mL}$ with diluent $(0.16$ $\mathrm{mg} / \mathrm{mL}$ of Azilsartan Medoxomil).[2] 
Selection of Wavelength:

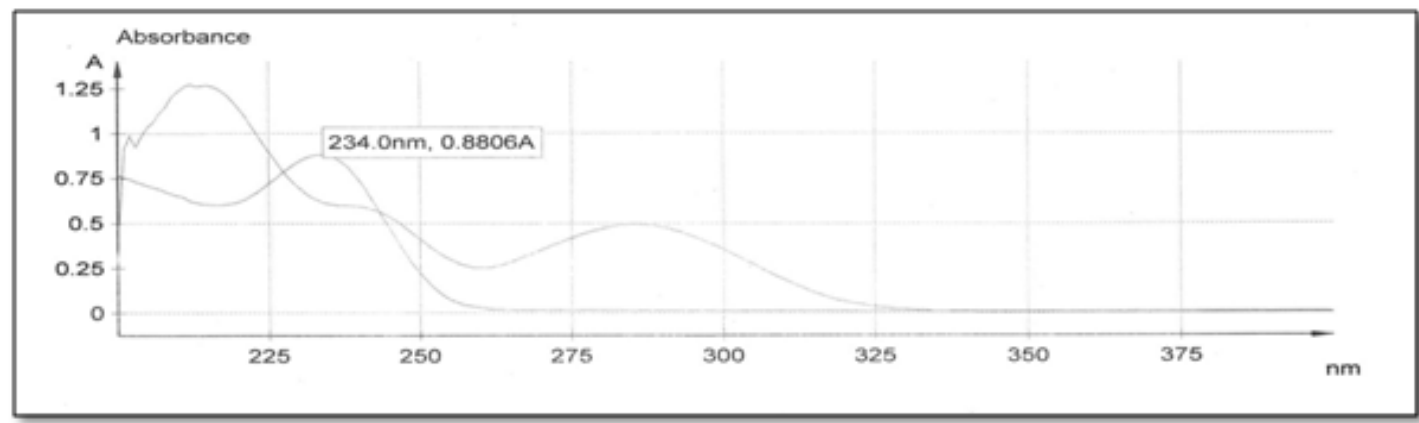

Fig 3 Spectra showing $\lambda$ max of Chlorthalidone \& Azilsartan Medoxomil

Optimized Chromatographic Condition:

\begin{tabular}{|l|c|l|}
\hline Column & $:$ & $\begin{array}{l}\text { Zorbax XBD-C8, 250 } \mathrm{mm} \times 4.6 \mathrm{~mm}, 5 \mu \mathrm{m} \text { or equivalent } \\
\text { Part No.990967-906 }\end{array}$ \\
\hline Mobile Phase & & Buffer pH5.5::methanol $(60: 40 / \mathrm{v})$ \\
\hline Flow Rate & $:$ & $1.0 \mathrm{~mL} / \mathrm{min}$ \\
\hline Injection Volume & $:$ & $25 \mu \mathrm{L}$ \\
\hline Wavelength & $:$ & $234 \mathrm{~nm}$ \\
\hline
\end{tabular}

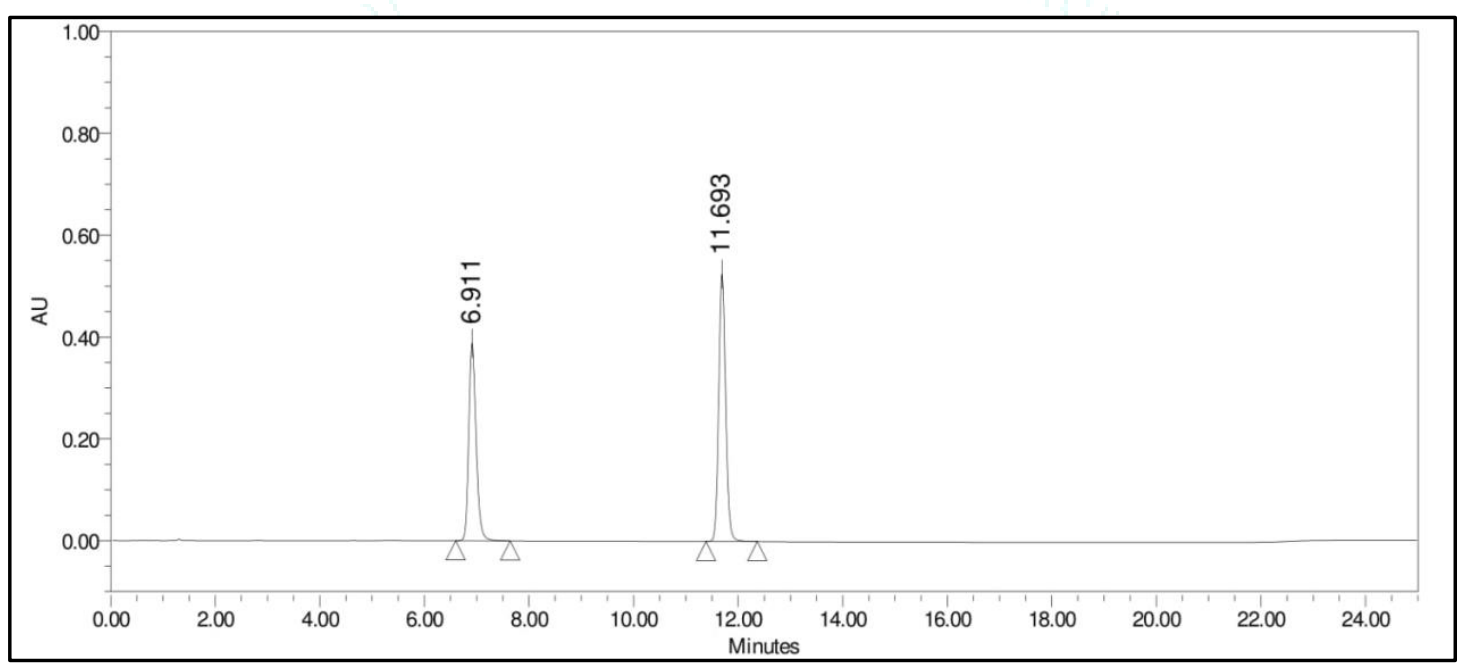

Fig. 4 Typical Optimised chromatogram Azilsartan Medoxomil, Chlorthalidone

Result and Discussion -

Table 3: Result of linearity.

\begin{tabular}{|c|c|c|c|}
\hline $\begin{array}{c}\text { Conc.of Chlorthalidone } \\
\text { HCL( conc in ppm ) }\end{array}$ & Area & $\begin{array}{c}\text { Conc. of AzilsartanMedoxomil. (conc } \\
\text { in ppm) }\end{array}$ & Area \\
\hline 50.56 & 1245690 & 80.010 & 2419267 \\
\hline 76.8 & 1875783 & 121.615 & 3184787 \\
\hline 101.12 & 2470595 & 160.020 & 4069226 \\
\hline 127.41 & 3200029 & 201.625 & 4857134 \\
\hline 151.68 & 3819248 & 240.030 & \\
\hline
\end{tabular}




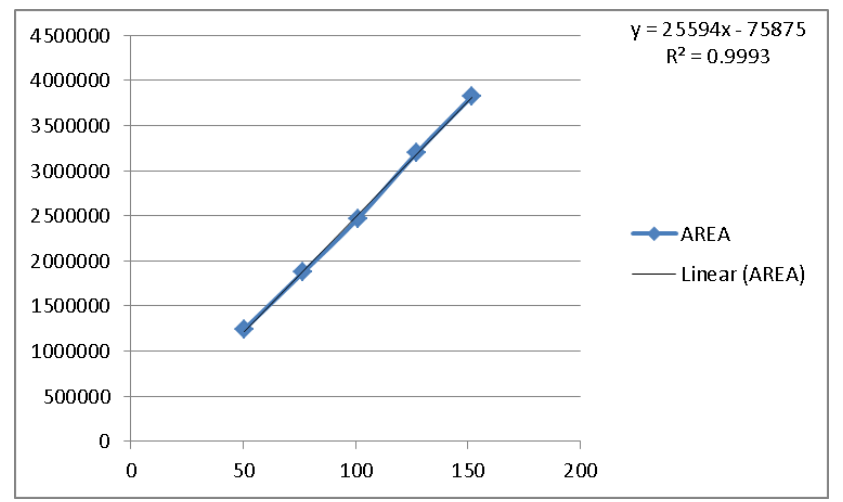

Fig.No. 5.Linearity graph for Chlorthalidone HCL.

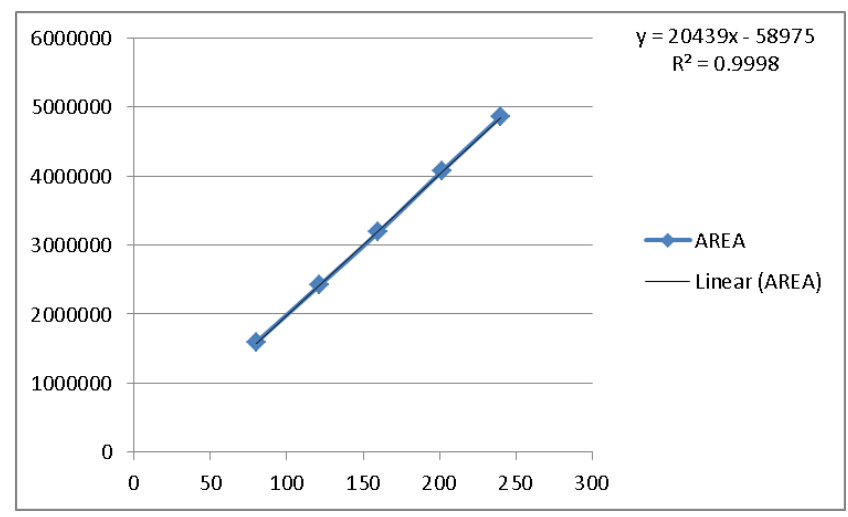

Fig.No 6.Linearity graph for AzilsartanMedoxomil.

Table 4: \% Recovery data for Chlorthalidone HCL and AzilsartanMedoxomil

\begin{tabular}{|l|l|l|c|}
\hline Drug & \% Composition & \% Recovery & \% mean RSD \\
\hline \multirow{3}{*}{ Chlorthalidone HCL } & 50 & 100.4 & \\
\cline { 2 - 3 } & 100 & 98.01 & \\
\cline { 2 - 3 } & 150 & 100.02 & \\
\hline \multirow{3}{*}{ Azilsartan Medoxomil. } & 50 & 100.00 & \\
\cline { 2 - 3 } & 100 & 100.5 & \\
\cline { 2 - 3 } & 150 & 99.01 & \\
\hline
\end{tabular}

Robustness:

Table 5 Robustness for Chlorthalidone

\begin{tabular}{|c|c|c|c|c|c|c|c|}
\hline $\begin{array}{l}\text { Changes in } \\
\text { parameters }\end{array}$ & Values & $\begin{array}{l}\text { Retention Time of } \\
\text { Chlorthalidonepeak }\end{array}$ & $\begin{array}{l}\text { Symmetry } \\
\text { Factor }\end{array}$ & $\begin{array}{c}\text { Theoretical } \\
\text { plates }\end{array}$ & $\begin{array}{c}\text { \% RSD of } \\
\text { standard } \\
\text { area }\end{array}$ & $\begin{array}{c}\% \\
\text { Assay }\end{array}$ & $\begin{array}{l}\text { Absolute } \\
\text { difference }\end{array}$ \\
\hline Control & $\begin{array}{l}\text { As per } \\
\text { method }\end{array}$ & 6.757 & 1.17 & 10536 & 0.41 & 100.7 & - \\
\hline \multirow[t]{2}{*}{$\begin{array}{c}\text { Flow rate } \\
( \pm 0.1 \mathrm{~mL} / \mathrm{min})\end{array}$} & $\begin{array}{c}+0.1 \\
\mathrm{~mL} / \mathrm{min}\end{array}$ & 6.030 & 1.17 & 8824 & 0.65 & 99.9 & 0.6 \\
\hline & $\begin{array}{c}-0.1 \\
\mathrm{~mL} / \mathrm{min}\end{array}$ & 7.304 & 1.18 & 12176 & 0.12 & 100.0 & 0.7 \\
\hline \multirow{2}{*}{$\begin{array}{l}\text { Change in } \\
\text { Wavelength } \\
( \pm 5 \mathrm{~nm})\end{array}$} & $+5 \mathrm{~nm}$ & 6.880 & 1.21 & 11758 & 0.20 & 100.3 & 0.4 \\
\hline & $-5 \mathrm{~nm}$ & 6.880 & 1.22 & 11770 & 0.21 & 100.6 & 0.1 \\
\hline \multirow{3}{*}{$\begin{array}{l}\text { Change in Column } \\
\text { temperature } \\
\left( \pm 5^{\circ} \mathrm{C}\right)\end{array}$} & $+5^{\circ} \mathrm{C}$ & 6.147 & 1.17 & 9259 & 0.12 & 98.9 & 1.8 \\
\hline & $-5^{\circ} \mathrm{C}$ & 6.404 & 1.18 & 9809 & 0.46 & 99.8 & 0.9 \\
\hline & & & & & & & \\
\hline
\end{tabular}

Table 6 Robustness for Azilsartan Medoxomil

\begin{tabular}{|c|c|c|c|c|c|c|c|}
\hline $\begin{array}{c}\text { Changes in } \\
\text { parameters }\end{array}$ & Values & $\begin{array}{c}\text { Retention Time of } \\
\text { AzilsartanMedoxomil } \\
\text { peak }\end{array}$ & $\begin{array}{c}\text { Symmetry } \\
\text { Factor }\end{array}$ & $\begin{array}{c}\text { Theoretical } \\
\text { plates }\end{array}$ & $\begin{array}{c}\text { \% RSD of } \\
\text { standard } \\
\text { area }\end{array}$ & $\begin{array}{c}\text { \% } \\
\text { Assay }\end{array}$ & $\begin{array}{c}\text { Absolute } \\
\text { difference }\end{array}$ \\
\hline Control & $\begin{array}{c}\text { As per } \\
\text { method }\end{array}$ & 11.801 & 1.08 & 36432 & 0.32 & 100.9 & - \\
\hline $\begin{array}{c}\text { Flow rate } \\
\pm 0.1 \mathrm{~mL} / \mathrm{min})\end{array}$ & $\begin{array}{c}+0.1 \\
\mathrm{~mL} / \mathrm{min}\end{array}$ & 10.997 & 1.08 & 33021 & 0.29 & 100.4 & 0.5 \\
\cline { 2 - 8 } & -0.1 & 12.433 & 1.09 & 40650 & 0.04 & 101.6 & 0.7 \\
\hline $\begin{array}{c}\text { Change in } \\
\text { Wavelength }( \pm 5 \\
\mathrm{nm})\end{array}$ & $+5 \mathrm{~nm}$ & 11.638 & 1.11 & 37461 & 0.13 & 100.9 & 0.0 \\
\hline $\begin{array}{c}\text { Change in } \\
\text { Column } \\
\text { temperature } \\
\left( \pm 5^{\circ} \mathrm{C}\right)\end{array}$ & $-5 \mathrm{~nm}$ & 11.638 & 1.11 & 37491 & 0.18 & 100.4 & 0.5 \\
\cline { 2 - 8 } & $-5^{\circ} \mathrm{C}$ & 11.195 & 1.08 & 35529 & 0.09 & 100.0 & 0.9 \\
\hline
\end{tabular}




\section{CONCLUSION}

The proposed simultaneous eatimation and validation method was found to be simple, precise, accurate and rapid for the determination of Chlorthalidone and AzilsartanMedoxomil.The coefficient of correlation was obtained in acceptable range .The percentage recovery obtained in acceptable range .variation in flow rate, wavelength, does not have any effect on the \% RSD of standard and assay value.There lative standard deviation of main peak area ,tailing factor and therotical plate is well within the acceptable range. Hence the precision of given method is confirmed. Thus from the above result of the individual method is conclude that the analytical method is validated and found to be satisfactory.

\section{ACKNOWLEDGMENT}

The authors express their gratitude to the Pravara Rural College of Pharmacy,Loni and a division of Amoli lab Limited,Mumbai and Honour limted Hydrabad for providing the gift sample of Azisartan medoximil and Chlorthalidone.

\section{REFERENCES}

1. Nair S, Wilding JP. Sodium glucose cotransporter 2 inhibitors as a new treatment for diabetes mellitus. J ClinEndocrinolMetab, (2010); 5(1), page no:34-42.
2. Strojek K, Yoon KH, Hruba V, Elze M, Langkilde AM, Parikh S, et al. Effect ofdapagliflozin in patients with type 2 diabetes who have inadequate glycaemic control withglimepiride: a randomized, 24-week, double- blind, placebo-controlled trial. DiabetesObesMetab,(2011); 13(10):page no : 928-938.

3. Kim Y, Babu AR. Clinicalotential of sodium- glucose cotransporter 2 inhibitors in the management of type 2 diabetes. Diabetes MetabSyndrObes, (2012); 5(3),page no :313-327.

4. Janssen Research \& Development, LLC. Canagliflozin as an adjunctive treatment to diet and exercise alone or coadministered with other antihyperglycemic agents to improve glycemic control in adults with type 2 diabetes mellitus ,(2013), page no :224-231.

5. http://www.mediclnewstoday.com

6. http://www.thediabeticvoice.com

7. Cindy Green, RAC. A Step By Step Approach to Establishing a Method Validation. Journal of Validation Technology August 2007; 13(4):p.317-323

8. Vasant D. Khasia, Hetal V. Khasia, Dhara Desai, Dharmishtha N. Bhakhar, Ashok R. Parmar, "Development and Validation of Stability Indicating RP-HPLC Method for Immediate Release Tablet Dosage Form", Journal of Pharmacy research, 2012, 5(8),4115-4118. 